\begin{tabular}{|c|}
\hline 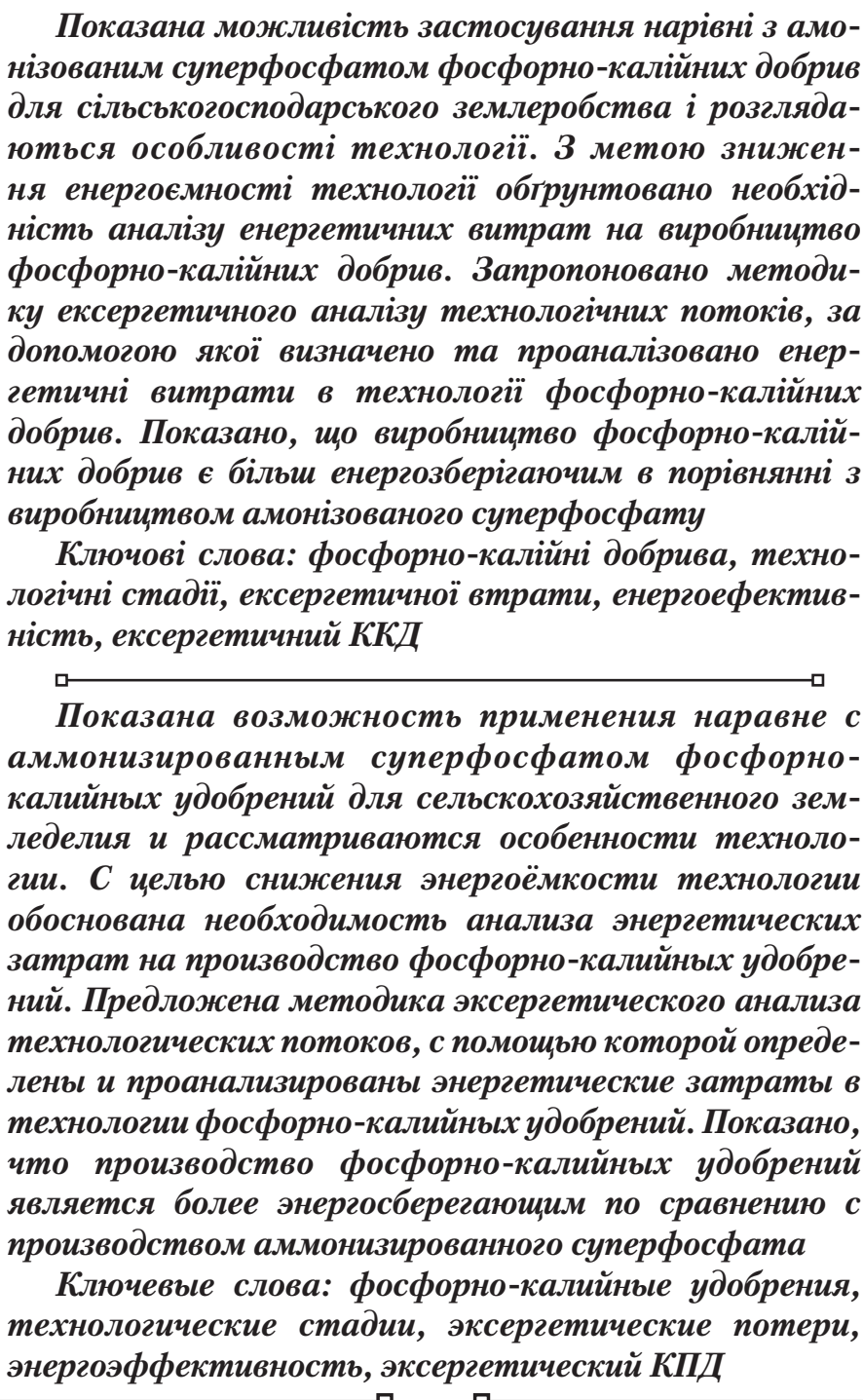 \\
\hline
\end{tabular}
нізованим суперфосфатом фосфорно-калійних добрив

\title{
THE EXERGY ANALYSIS OF ENERGY EFFICIENCY OF THE TECHNOLOGY OF GRANULATED PHOSPHORUS- POTASSIUM FERTILIZERS
}

\author{
N. Y u k h i m e n k o \\ $\mathrm{PhD}$, Associate Professor \\ Department of Processes and \\ Equipment of Chemical and Petroleum-Refineries \\ Sumy State University \\ Rymskogo-Korsakova str., 2, \\ Sumy, Ukraine, 40007 \\ E-mail: yunp@ukr.net \\ S. V a k a I \\ $\mathrm{PhD}$, Associate Professor, Director \\ SE "Sumy State Scientific Research Institute of \\ Mineral Fertilizers and Pigments" \\ Kharkivska str., $12 \mathrm{p} / \mathrm{o}$, \\ Sumy, Ukraine, 40030 \\ E-mail: vacal@mail.ru
}

\section{Introduction}

Mineral granulated fertilizers are one of the most important types of the products of chemical industry for agriculture. The nitrogen and phosphate fertilizers dominate the assortment of mineral granulated fertilizers [1-4]. Double and ammoniated superphosphate are the most demanded by users among the phosphate fertilizers.

Under conditions of agriculture, the compensation for the losses of nutrients in soil by applying traditional phosphate mineral fertilizers cannot be sufficient enough. Therefore, for provision of the proper conditions of increasing the fertility of soils it is necessary to create the complex mineral fertilizers, whose chemical composition is determined by the agro-ecological conditions of their application. Such fertilizers include granulated phosphorus and potassium fertilizers.

The technology, developed at GP "Sumy State Institute of Mineral Fertilizers and Pigments", of granulation of phosphorus and potassium fertilizers by the semi-dry method consists in the agglomeration of ground rock phosphate with the aid of plasticizer on the base of the compounds of potassium at humidity of the charge not higher than $12 \%$. The advantages of the designed technology consist in the direct application of phosphorites without their additional crushing, in the use of the raw material that contains potassium as the plasticizer, in the possibility to refrain from treating the obtained fertilizer with preparations - loosening materials.

The phosphorus and potassium fertilizers of the $\mathrm{NPK}=0: 13: 13$ and 0:17:5 types are a certain alternative for ammoniated superphosphate that make it possible to decrease the deficit in the need of agrarians for a basic fertilizer. The availability of potassium and magnesium in this fertilizer compensates for the costs, associated with the fact that $1 \mathrm{t}$ of ammoniated superphosphate by phosphorus is equivalent to $1,42 \mathrm{t}$ of this fertilizer. The given types of fertilizer are intended for the application in farm, forestry and home gardens in all types of soils and for all agricultural crops. 


\section{Literature review and problem statement}

In the technology of manufacturing granular fertilizers, the availability of phase transitions predetermines significant consumption of thermal energy. And the given technologies imply the use of a drying-granulating drum (DGD) as the main unit, which is characterized by the lowest energy efficiency, whose magnitude is determined as the ratio of consumption of the product to the energy consumption (electrical or thermal), used by the unit [5].

According to the data [5], the energy costs for obtaining double and ammoniated superphosphate are 1,5-1,7 larger in comparison to the manufacturing of ammophos and nitroammophoska. The detailed analysis of energy consumption in the course of manufacturing of ammoniated superphosphate, presented in work [5], revealed significant energy losses, especially at the stage of granulation of pulp and drying of granules, i. e., where there are phase transitions. Since the technology of phosphorus and potassium fertilizers is based on the fabrication of granules by the method of pelleting, it does not imply the presence of phase transitions. That is why one should expect that this technology would possess lower power consumption, and, therefore, the important question is the analysis of the completeness of the use of thermal energy supplied to the main technological equipment for the purpose of efficiency of the technology of obtaining phosphorus and potassium fertilizers.

However, the necessity to take into account, as a result of the analysis, not only the amount of energy, consumed and returned by the technical system, but also the quality of this energy (i.e., its capacity to be converted to useful work), led to the appropriateness of applying the exergy analysis.

A number of studies are dedicated to the estimation of energy losses with the aid of the exergy analysis when conducting technological processes in different sectors of industry. Paper [6] examines the exergy analysis and power costs of technological stages of fuel combustion. The method of the estimation of power expenses, presented in the paper, contains analytical dependences, which can be used only for specific fuel technologies. Article [7] addresses, with the aid of the exergy analysis, the questions of energy saving in the production of nitric acid and presents results of the calculations in connection with the indicated manufacturing process. Publication [8] presents the ways of reducing the energy costs in the manufacturing of cement clinker, the represented equations for evaluating the exergy losses have generalized character; however, the results of calculations are analyzed for a partucular manufacturing process. Paper [9] proposes to use the exergy analysis for evaluating the energy efficiency of producing bio fuel, special features of power consumption during chemical and biochemical processes are examined, the exergy efficiency in the manufacturing of different bio fuels is compared.

Applicability of the exergy analysis in the technology of production of mineral fertilizers, namely, ammonium nitrate, is demonstrated in paper [10]. However, the exergy method is examined in connection to evaluation of the effect of waste and emissions on environment, i.e., from an ecological point of view without analysis of energy consumption particularly during the technological stages of production. Article [11] considers questions of energy saving and the ways of reducing the energy costs only for the production of nitrogen fertilizers.
Thus, the analysis of the sources given above reveals that the method of exergy analysis is applied in different sectors of chemical technology. Results of the analysis are of practical nature since technological stages of the production processes in question differ considerably from each other. That is why they cannot be disseminated to the technology of phosphate fertilizers. The Author's paper [5] is dedicated to the exergy analysis of technological stages of production of ammoniated superphosphate, it contains only the results of analysis while the method of analysis is lacking in it. The data of results of analytical calculations, presented in article [5], are not applicable to technology of phosphorus and potassium fertilizers since the semi-dry process of granulation predetermines specific technological modes, which differ from the modes of production of ammoniated superphosphate.

\section{Aim and objectives of the research}

The purpose of the work is developing the method of the exergy analysis of technological flows, which makes it possible to estimate the exergy losses by each technological stage and to determine energy efficiency of production of phosphorus and potassium fertilizers.

To achieve the set aim, the following tasks are to be solved:

- to define the main types of the exergy losses with technological flows in the system "unit - the environment" and to propose the method for determining the exergy losses in the production of phosphorus and potassium fertilizers;

- to carry out the estimation of energy costs and to find the most energy-consuming technological stages in the production of phosphorus and potassium fertilizers;

- to conduct the comparison of energy costs in the production of phosphorus and potassium fertilizers and ammoniated superphosphate with the purpose of determining the lowest consumption of the given technologies.

\section{Characteristic of technological stages of obtaining the phosphorus and potassium fertilizers}

The technological parameters of obtaining phosphorus and potassium fertilizers, determined in the course of the studies, were included in the initial data on design and formed the basis of the project for production of phosphorus and potassium fertilizers with capacity of 5 tons per hour, implemented by the GP "Sumy State Institute of Mineral Fertilizers and Pigments".

The schematic diagram of material flows by the technological stages of the operating production of phosphorus and potassium fertilizers without regard to mechanical losses is shown in Fig. 1. The scheme displays mass consumption of raw materials, products and flue gases, which correspond to the material balance in the conversion per the ton of finished product, as well as temperature modes, in line with the standards of technological regulations of production.

The process of obtaining granulated phosphorus and potassium fertilizer consists of the auxiliary stages:

- preparation of raw material (Fig. 1, designated by dark-blue blocks);

- obtaining flue gases (Fig. 1, designated by red block);

- purification of exhaust gases (Fig. 1, designated by lilac block); 
- the main stages: mixing of components, granulation, drying and classification of granules by sizes to the commercial and fine fractions (in Fig. 1 they are designated by gray blocks).

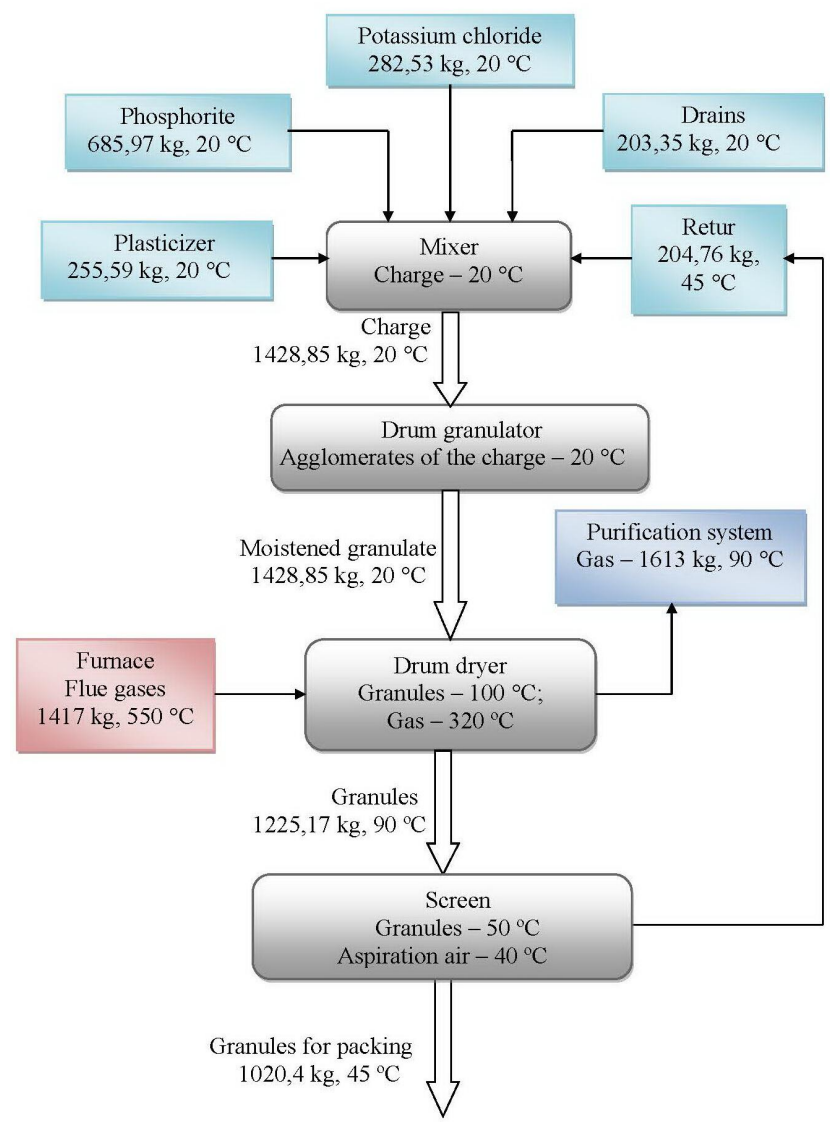

Fig. 1. Structural scheme of technology of phosphorus and potassium fertilizers

The preparation stage of raw material consists in accepting and storing of raw material, crushing of raw components and preparation of a plasticizer on the base of the potassium-containing raw materials. At the stage of preparation of the plasticizer, the preparation of a binder occurs, as well as preliminary moistening of phosphate raw material to humidity not larger than $12 \%$ for its subsequent granulation. At the stage of granulation, the moistened charge enters the drum granulator where the granules are formed. During their motion in the granulator, the granules are compacted, a part of the liquid phase is extruded to the surface of the growing granule that creates conditions of adhesion of new small particles to the growing granule. The formed granules then enter the stage of drying into the drying drum, where, in the process of drying by flue gases, vapors of water are released to the gas phase and the amount of liquid phase in the granules decreases. The dried granules enter the screen, in which classification of granules into the commercial and fine fractions takes place with the latter returning to the stage of mixing as retur. At the stage of dry purification of gases in a battery cyclone, the solid particles, being carried away by the flow, are preliminarily captured and returned, also as retur, to the stage of mixing. The gas flow, which contains the smallest particles, enters the stage of wet purification in the scrubber, which is fed with the watering liquid. Part of the worked-out scrubber liquid is supplied to the stage of preparation of plasticizer. Simultaneously, industrial water is fed to the circulating system.

\section{Method of the exergy analysis of technology flows}

Technological processes of chemical production require certain expenses of energy in its diverse forms. The intensity and economic efficiency of the course of the process depend on the fact how fully the supplied energy is used. The essence of the exergy analysis consists in compiling the exergy balance of the considered technical system [12-17].

Energy (thermal) balance uniquely determines the equality of heat fluxes incoming and outgoing from the technical system while in the exergy balance the expenditure part of the balance equation is always less than the incoming part [17]. Thus, thermal balance by its nature cannot represent the loss from irreversibility of processes in the technical system because, independent of the degree of its perfection, the equality will be maintained. The inapplicability of thermal balance for estimation of energy expenses in technological processes is demonstrated in paper [18]. The exergy balance, on the contrary, in all cases displays the magnitude of losses from the irreversibility in a technical system.

In general form, the exergy balance takes the form:

$$
\sum \mathrm{E}_{\mathrm{en}}=\sum \mathrm{E}_{\mathrm{ex}}+\sum \mathrm{E}_{\mathrm{los}} \text {, }
$$

where $\sum \mathrm{E}_{\mathrm{en}}$ is the summary exergy, delivered to the technical system with technology flows, $\mathrm{J} ; \sum \mathrm{E}_{\mathrm{ex}}$ is the summary exergy, diverted from the technical system with technology flows, J; $\Sigma \mathrm{E}_{\text {los }}$ is the summary losses of exergy with technology flows, J.

The exergies of technology flows are determined depending on their aggregate state and are equal to:

$$
\begin{aligned}
& E_{s, f}=G \cdot c \cdot\left[\left(T-T_{0}\right)-T_{0} \cdot \ln \frac{T}{T_{0}}\right], \\
& E_{g, s t}=G \cdot\left[\left(i-i_{0}\right)-T_{0} \cdot\left(s-s_{0}\right)\right]= \\
& =G \cdot\left[\left(i-i_{0}\right)-T_{0} \cdot\left(\frac{i}{T}-\frac{i_{0}}{T_{0}}\right)\right],
\end{aligned}
$$

where $E_{s, f}$, is the magnitude of exergy of the technology flow, which is in the solid or liquid state of aggregation, J; $E_{g, s t}$ is the magnitude of exergy of the technology flow, which is in a gaseous or vaporous state of aggregation, J; $\mathrm{G}$ is theamount of material flow (substance), $\mathrm{kg}$; $\mathrm{c}$ is the heat capacity of substance, $\mathrm{J} /(\mathrm{kg} \cdot \mathrm{K})$; $\mathrm{T}$ is the absolute temperature of technology flow under operation conditions, K; $\mathrm{T}_{0}$ is the absolute temperature of technology flow under environmental conditions, $\mathrm{K} ; \mathrm{i}, \mathrm{i}_{0}$ are the gas enthalpy or steam, respectively, under certain conditions, $\mathrm{J} / \mathrm{kg} ; \mathrm{s}, \mathrm{s}_{0}$ are the specific enthropy of gas or steam, respectively, under certain conditions, $\mathrm{J} /(\mathrm{kg} \cdot \mathrm{K})$.

For the heat-utilizing equipment, the losses of exergy are caused by three main factors: by the change in the magnitude of pressure of the medium on the border "input-output" $\left(E_{\mathrm{p}}\right)$, by the heat losses through the unit's walls to the environment $\left(\mathrm{E}_{0}\right)$ and by the heat exchange at finite differences in temperatures of technology flows at the input to the unit and at the output from it $\left(\mathrm{E}_{\mathrm{T}}\right)$. The losses, indicated accordingly, are equal to:

$$
\mathrm{E}_{\mathrm{P}}=\mathrm{T}_{0} \mathrm{R} \ln \frac{\mathrm{P}_{\mathrm{en}}}{\mathrm{P}_{\mathrm{ex}}}=\mathrm{T}_{0} \mathrm{R} \ln \left(\frac{\left(\mathrm{P}_{\mathrm{ex}}+\Delta \mathrm{P}\right)}{\mathrm{P}_{\mathrm{ex}}}\right),
$$




$$
\begin{aligned}
& \mathrm{E}_{0}=\mathrm{Q} \frac{\mathrm{T}_{\mathrm{ins}}-\mathrm{T}_{0}}{\mathrm{~T}_{\mathrm{ins}}}=\mathrm{Q}\left(1-\frac{\mathrm{T}_{0}}{\mathrm{~T}_{\mathrm{ins}}}\right), \\
& \mathrm{E}_{\mathrm{T}}=\Delta \mathrm{s} \cdot \mathrm{T}_{0}=\mathrm{T}_{0} \cdot\left(\mathrm{G}_{\mathrm{h}} \cdot \mathrm{C}_{\mathrm{h}} \int_{\mathrm{T}_{\mathrm{hf}}}^{\mathrm{T}_{\mathrm{he}}} \frac{\mathrm{dT}_{\mathrm{h}}}{\mathrm{T}_{\mathrm{h}}}-\mathrm{G}_{\mathrm{c}} \cdot \mathrm{C}_{\mathrm{c}} \int_{\mathrm{T}_{\mathrm{ce}}}^{\mathrm{T}_{\mathrm{cf}}} \frac{\mathrm{dT}_{\mathrm{c}}}{\mathrm{T}_{\mathrm{c}}}\right)= \\
& =\mathrm{T}_{0} \cdot\left(\mathrm{W}_{\mathrm{h}} \cdot \ln \frac{\mathrm{T}_{\mathrm{hf}}}{\mathrm{T}_{\mathrm{he}}}+\mathrm{W}_{\mathrm{c}} \cdot \ln \frac{\mathrm{T}_{\mathrm{cf}}}{\mathrm{T}_{\mathrm{ce}}}\right),
\end{aligned}
$$

where $\mathrm{R}$ is the gas constant, $\mathrm{J} / \mathrm{mol} \cdot \mathrm{K} ; \mathrm{P}_{\mathrm{en}}, \mathrm{P}_{\mathrm{ex}}$ are the pressure of liquid or gas-vaporous flow at the inputof the unit and the output from it, respectively, $\mathrm{Pa} ; \Delta \mathrm{P}$ is thepressure drop in the system, $\Delta \mathrm{P}=\mathrm{P}_{\text {en }}-\mathrm{P}_{\text {ex }}, \mathrm{Pa} ; \Delta \mathrm{s}$ is the sum of increases in the entropies of heated and cold technology flow, $\mathrm{J} / \mathrm{kg} \cdot \mathrm{K}$; $\mathrm{Q}$ is the thermal load of the unit, $\mathrm{W} ; \mathrm{W}_{\mathrm{h}}$ is the water equivalent of the heated technology flow, equal to the product of theamount of the flow $\left(\mathrm{G}_{\mathrm{h}}\right)$ to its heat capacity $\left(\mathrm{C}_{\mathrm{h}}\right), \mathrm{J} / \mathrm{K}$; $\mathrm{W}_{\mathrm{c}}$ is the water equivalent of cold technology flow, equal to the product of theamount of the flow $\left(G_{c}\right)$ to its heat capacity $\left(\mathrm{C}_{\mathrm{c}}\right), \mathrm{J} / \mathrm{K} ; \mathrm{T}_{\mathrm{h}}$ is the current absolute temperature of heated technology flow, $\mathrm{K} ; \mathrm{T}_{\mathrm{c}}$ is the current absolute temperature of cold technology flow, $\mathrm{K} ; \mathrm{T}_{\text {he }}, \mathrm{T}_{\mathrm{ce}}, \mathrm{T}_{\mathrm{hf}}, \mathrm{T}_{\mathrm{cf}}$ are the initial temperature of the heated and cold technology flow at the inputof the unit, the final temperature of the heated and cold technology flowat the output of the unit, respectively, K; $\mathrm{T}_{\text {ins }}$ is the average temperature of the insulation of the unit's walls, $\mathrm{K}$ (it is selected according to DSTU EN 563-2001 and it must not exceed $43^{\circ} \mathrm{C}$ ).

The first two types of losses relate to the technical ones, i. e., for their decrease it is necessary to take only technical measures: to increase the flow area of working volume, to decrease the number of contact elements, to increase thickness of thermal insulation layer on the external walls of equipment. This approach is extensive and its implementation often requires significant capital expenditures. The third type of the exergy losses can be attributed to the technological ones and for their decrease, it is necessary to strive for reaching the maximum final temperature of the cold flow and the minimum final temperature of the heated flow at the output from the unit. Thus, the less the difference in temperatures for technology flows at the output from the unit, the less the exergy losses, the higher the value of the exergy performance efficiency $\left(\eta_{\mathrm{e}}\right)$; the unit accordingly will have better energy efficiency.

The exergy performance efficiency, without taking into account losses from the change in the magnitude of the pressure of medium due its smallness, is equal to:

$$
\begin{aligned}
& \eta_{\mathrm{e}}=\frac{\mathrm{E}_{\mathrm{ex}}}{\mathrm{E}_{\mathrm{en}}}=\frac{\mathrm{E}_{\mathrm{en}}-\left(\mathrm{E}_{\mathrm{T}}+\mathrm{E}_{0}\right)}{\mathrm{E}_{\mathrm{en}}}= \\
& =\frac{\mathrm{Q}\left(1-\mathrm{T}_{0} / \mathrm{T}_{\mathrm{he}}\right)-\left(\mathrm{T}_{0}\left(\mathrm{~W}_{\mathrm{h}} \ell \mathrm{n}\left(\mathrm{T}_{\mathrm{hf}} / \mathrm{T}_{\mathrm{he}}\right)+\mathrm{W}_{\mathrm{c}} \ell \mathrm{n}\left(\mathrm{T}_{\mathrm{cf}} / \mathrm{T}_{\mathrm{ce}}\right)\right)+\mathrm{Q}\left(1-\frac{\mathrm{T}_{0}}{\mathrm{~T}_{\mathrm{ins}}}\right)\right)}{\mathrm{Q}\left(1-\mathrm{T}_{0} / \mathrm{T}_{\mathrm{he}}\right)}= \\
& =1-\frac{\mathrm{T}_{0}\left(\mathrm{~W}_{\mathrm{h}} \ell \mathrm{n}\left(\mathrm{T}_{\mathrm{hf}} / \mathrm{T}_{\mathrm{he}}\right)+\mathrm{W}_{\mathrm{c}} \ell \mathrm{n}\left(\mathrm{T}_{\mathrm{cf}} / \mathrm{T}_{\mathrm{ce}}\right)\right)+\mathrm{Q}\left(1-\frac{\mathrm{T}_{0}}{\mathrm{~T}_{\text {ins }}}\right)}{\mathrm{Q}\left(1-\mathrm{T}_{0} / \mathrm{T}_{\mathrm{he}}\right)} .
\end{aligned}
$$

The exergy performance efficiency $\left(\eta_{\mathrm{e}}\right)$ will determine more accurately, in comparison with the thermal efficiency, the exergy value of technology flows. In this case, the ex- ergy performance efficiency completely satisfies general requirements: for the ideal process, when the losses of exergy are absent, $\eta_{\mathrm{e}}=1(100 \%)$; if the supplied exergy is completely lost in the process, then $\eta_{\mathrm{e}}=0$; the difference between the exergy incoming to the object and outgoing from it is always equal to the summary losses and in the real processes $-0<\eta_{\mathrm{e}}<1$. I. e., the magnitude of exergy losses is the most important characteristic of the exergy analysis. It is possible to judge energy perfection of the considered technological equipment by it. The larger the loss of exergy, the less $\eta_{\mathrm{e}}$ and vice versa. Thus, the energy efficiency of the used equipment will be larger or smaller. If the technological equipment has low energy efficiency (conditionally, $\eta_{\mathrm{e}}<50 \%$ ), then it is necessary to outline the ways of reducing the exergy losses and increasing the exergy efficiency accordingly.

The nature and magnitude of negative effect of the heat fluxes, released by technical system into the environment, is in direct dependence on the exergy of the given flows. That is why for designing energy-saving measures it is necessary, with the help of the exergy analysis, to quantitatively determine the exergies of heat fluxes and to define the conditions, which make it possible to decrease the exergy of outflow heat fluxes and in doing so to increase the exergy performance efficiency of the technical object.

\section{The exergy analysis of the technology of phosphorus and potassium fertilizers}

As the object of the exergy analysis, we examined the technology of obtaining granular fertilizers of the NPK=0:13:13 type, developed at the GP "Sumy State Institute of Mineral Fertilizers and Pigments" on the base of phosphorites from the Egoriev deposit, in line with the TU 14.3-14005076-072:2007. The addition of chloride potassium, according to the TU 2184023-05778557-2005, was introduced to the composition of charge by two flows: part in the form of powder and part in the form of solution-plasticizer. As shown in Fig. 1, five components are supplied to the stage of mixing the charge.

The exergy analysis of the technology of phosphorus and potassium fertilizers was conducted by the stages: mixing of raw material in the mixer, granulation of the charge in the drum granulator; drying of granules in the dryer drum, sieving of the obtained granules in the mechanical screen.

The method of composition of the exergy balance consists of the following stages:

1) material flows are defined with the indication of mass expenses, the temperatures at the unit's input, in the working volume of the unit and at its output (Fig. 1). The heat capacity of granules, the enthalpies of flue gas, outgoing gas flow and aspiration air at corresponding temperatures are the reference data;

2) the exergies of the flows of granules, dust of phosphorite, potassium chloride and retur are determined in accordance with the technological stages by the formula (2);

3 ) the exergies of flue, outgoing gases and aspiration air are determined in accordance with the technological stages by the formula (3); 
4) the exergy losses are determined as the difference between the input and consumption of the exergy flows;

$5)$ the types of the exergy losses are determined, namely, from the heat exchange with the environment by the formula (5) and due to imperfection of the heat exchange with a finite difference in temperatures by the formula (6);

6 ) the exergy performance efficiency of the main units of each technological stage is determined by the formula (7).

The exergy balance and the values of exergy performance efficiency for each technological stage are shown in Table 1.

Since no change in the temperatures of technology flows occurs at the stages of mixing the raw materials and granulation of the charge, the exergy of the given flows equals zero and there are no exergy losses.

At the stage of the drying of granules, the central unit (as, however, of the entire technological scheme) is the drum dryer, which has, according to the data [5], very low energy efficiency, equal to $0,02-0,03 \mathrm{~kg} / \mathrm{kJ}$. This is explained by the increased expenses, first of all, of electrical energy, for setting the multi-ton installation in rotation. With the outgoing gases, $436430 \mathrm{~kJ} / \mathrm{t}$ of exergy is consumed ( $97 \%$ of the total input), which is undoubtedly of practical interest for utilization of the heat of the outgoing gases with a temperature of $90-95{ }^{\circ} \mathrm{C}$. But the problem is in the fact that the outgoing gas, in addition to moisture, contains small particles of phosphorite and potassium chloride, which must be extracted from the outgoing flow by dry and wet purification, in the cyclones and scrubbers, respectively. Its temperature considerably reduces after irrigation of the outgoing gas by the scrubber liquid and such gas is converted to the low-potential, whose utilization is economically impractical since it leads to significant capital and operational costs.

Analysis of the exergy losses at the stage of drying revealed that significant reduction in the temperature of the drying agent from $550{ }^{\circ} \mathrm{C}$ to $90{ }^{\circ} \mathrm{C}$ predetermines practical absence of the losses (only $0,2 \%$ ) from the imperfection of the heat exchange with a finite difference in temperatures. I.e., as the heat-utilizing unit, which works according to the type of heat exchanger, the drum dryer works efficiently. However, the losses from the heat exchange with the environment in this case are significant (99\% of the total losses at the stage of drying). They are caused, first of all, by the heat losses through the walls of drum and bunkers, opened inspection windows, imperfect sealings. And while the two latter reasons of the heat losses are removed by technical (improvement of sealings) or disciplinary-technological (timely closing of inspection windows) solutions, then the first - by applying a heat-insulating layer on the external walls of the drum. The heat insulation will lead to saving the consumption of natural gas to $4-5 \%$ and decreasing the amount of flue gas by $2-3 \%$ that will reduce electricity consumption of the exhaust fan. On the other hand, the thermal insulation layer will increase the mass of the drum dryer, which will increase electricity consumption of the drum's drive. In addition to this, it is necessary to consider expenditures for thermal insulation material and the jacket and their complicated installation. That is why the efficiency of this approach is ambiguous and depends on the ratio of capital and operational expenditures.
Table 1

Summary exergy balance of the technology of phosphorus and potassium fertilizers

\begin{tabular}{|c|c|c|c|}
\hline Article of the balance & $\begin{array}{l}\text { Exergy, } \\
\mathrm{kJ} / \mathrm{t}\end{array}$ & $\begin{array}{c}\text { Proportion of } \\
\text { the amount of } \\
\text { expenditure, \% }\end{array}$ & \begin{tabular}{|c|} 
Exergy \\
performance \\
efficiency \\
$\left(\eta_{\mathrm{e}}\right), \%$
\end{tabular} \\
\hline 1. Mixing of raw materials & 0 & 0 & 0 \\
\hline 2. Granulation of the charge & 0 & 0 & 0 \\
\hline 3. Drying of granules & & & 84.7 \\
\hline $\begin{array}{l}\text { Input: } \\
\text { - with granules } \\
\left(1428,85 \mathrm{~kg} / \mathrm{t} ; 20^{\circ} \mathrm{C}\right) \text {; }\end{array}$ & 14947,2 & 3,31 & \\
\hline $\begin{array}{l}\text { - with flue gases } \\
\left(1417 \mathrm{~kg} / \mathrm{t} ; 550{ }^{\circ} \mathrm{C}\right)\end{array}$ & 436430,3 & 96,69 & \\
\hline Total & 451377,5 & 100 & \\
\hline $\begin{array}{l}\text { Consumption: } \\
\text { - with granules } \\
\left(1225,17 \mathrm{~kg} / \mathrm{t} ; 90^{\circ} \mathrm{C}\right) \text {; }\end{array}$ & 181,94 & 0,04 & \\
\hline $\begin{array}{l}\text { - with outgoing gases } \\
\left(1613,85 \mathrm{~kg} / \mathrm{t} ; 90^{\circ} \mathrm{C}\right)\end{array}$ & 382321,07 & 84,7 & \\
\hline $\begin{array}{l}\text { - with dust of phosphorite } \\
\text { and potassium chloride } \\
\left(6,83 \mathrm{~kg} / \mathrm{t}, 90^{\circ} \mathrm{C}\right)\end{array}$ & 1,01 & 0 & \\
\hline Total & 382504,02 & 84,74 & \\
\hline Losses & 68873,48 & 15,3 & \\
\hline $\begin{array}{l}\text { - due to imperfection of } \\
\text { the heat exchange with a finite } \\
\text { difference in temperatures; }\end{array}$ & 669,24 & 0,2 & \\
\hline $\begin{array}{l}\text { - from the heat exchange } \\
\text { with the environment }\end{array}$ & 68204,24 & 15,1 & \\
\hline 4. Sieving of granules & & & 16 \\
\hline $\begin{array}{l}\text { Input: } \\
\text { - with granules } \\
\left(1225,17 \mathrm{~kg} / \mathrm{t} ; 90^{\circ} \mathrm{C}\right) \text {; }\end{array}$ & 3086,2 & 35,4 & \\
\hline $\begin{array}{l}\text { - with aspiration air } \\
\left(756,1 \mathrm{~kg} / \mathrm{t} ; 20{ }^{\circ} \mathrm{C}\right)\end{array}$ & 5640,5 & 64,6 & \\
\hline Total & 8726,7 & 100 & \\
\hline Consumption: & & & \\
\hline $\begin{array}{l}\text { - with granules } \\
\left(1020,41 \mathrm{~kg} / \mathrm{t} ; 45^{\circ} \mathrm{C}\right) ;\end{array}$ & 43,78 & 0,5 & \\
\hline $\begin{array}{l}\text { - with retur } \\
\left(204,76 \mathrm{~kg} / \mathrm{t} ; 45^{\circ} \mathrm{C}\right)\end{array}$ & 8,78 & 0,1 & \\
\hline $\begin{array}{l}\text { - with aspiration air } \\
\left(756,1 \mathrm{~kg} / \mathrm{t} ; 35^{\circ} \mathrm{C}\right)\end{array}$ & 1383,7 & 15,9 & \\
\hline Total & 1436,3 & 16,5 & \\
\hline Losses & 7290,4 & 83,5 & \\
\hline $\begin{array}{l}\text { - due to imperfection of } \\
\text { the heat exchange with a finite } \\
\text { difference in temperatures; }\end{array}$ & 0 & 0 & \\
\hline $\begin{array}{l}\text { - from the heat exchange } \\
\text { with the environment }\end{array}$ & 7290,4 & 83,5 & \\
\hline
\end{tabular}

Thus, a drum dryer as the most energy-consuming component in the technological process is quite an effective device. The exergy analysis shows that the exergy losses are insignificant (only $15 \%$ of the total input), that is why exergy performance efficiency reaches rather high value of $85 \%$. This confirms that the heat of the drying agent is rationally used for removal of moisture while drying the wet charge. 
The exergy losses are significant at the stage of the seaving of finished granules (84\%) and they are caused only by the heat exchange with the environment. The heat from the heated dried granules is considerably lost during lifting by noria and the transshipment through the bunkers and conveyers, that is why the temperature of granules on the screen reaches $50{ }^{\circ} \mathrm{C}$ only while the temperature of outgoing aspiration air only $35^{\circ} \mathrm{C}$. Due to it, the exergy losses from the imperfection of the heat exchange with a finite difference in temperatures are absent.

Utilization of the heat of aspiration air with the purpose of decreasing the losses of exergy does not make any sense because the calculations showed that using such a low-potential $\left(35-45^{\circ} \mathrm{C}\right)$ heat for heating water (for technological or everyday purposes) may increase its temperature only by $5-9{ }^{\circ} \mathrm{C}$ from the initial, but the heat exchange surface in this case will reach $70-100 \mathrm{~m}^{2}$. This way is absolutely inacceptable since it will considerably increase capital and operational costs.

\section{Comparison of the energy expenses in the production of phosphorus and potassium fertilizers and ammoniated superphosphate}

For evaluating energy efficiency, it is necessary to compare power consumption in the production of phosphorus and potassium fertilizer and ammoniated superphosphate.

Let us present in Table 2 the summary exergy losses by the main technological stages of production of phosphorus and potassium fertilizer and ammoniated superphosphate.

Table 2

Exergy losses in the production of phosphorus and potassium fertilizer and ammoniated superphosphate

\begin{tabular}{|c|c|c|c|}
\hline \multirow{2}{*}{ No } & Technological stages & $\begin{array}{c}|c| \\
\text { ammoniated } \\
\text { superphos- } \\
\text { phate [5] }\end{array}$ & $\begin{array}{c}\text { phosphorus and } \\
\text { potassium fertilizer, } \\
\text { obtained by the } \\
\text { designed technology } \\
\text { (data from Table 1) }\end{array}$ \\
\hline 1 & Raw material processing & 31532 & 0 \\
\hline 2 & Granulation and drying & 212636 & 68874 \\
\hline 3 & Sieving of granules & 2963 & 7290 \\
\hline 4 & $\begin{array}{c}\text { Cooling of commercial } \\
\text { fraction }\end{array}$ & 7997 & - \\
\hline \multicolumn{2}{|c|}{ Total for production } & 255128 & 76164 \\
\hline
\end{tabular}

Comparison of the energy losses by the main technological stages demonstrates absence of losses at the stage of processing the raw material in the course of obtaining phosphorus and potassium fertilizers because of the temperature constancy of technology flows and cooling of the commodity fraction because of absence of this technological stage in the production, since the structure of granules is formed due to aggregation, stratification and particle compaction with the subsequent "fixing" the structure by the drying of granules.

An increase of the exergy losses by 2,5 times in the production of phosphorus and potassium fertilizers is caused by availability of additional transporting-bunker equipment, which leads to the larger heat losses through the walls of equipment. But the magnitude of the given losses with regard to the total losses is $10 \%$ for phosphorus and potassium fertilizers and only 1,2\% for ammoniated superphosphate, respectively. I. e., the indicated magnitudes of losses do not have a substantial influence on the production as a whole.

However, the main exergy losses are concentrated at the stages of granulation and drying in the production of both types of fertilizers. Moreover, during obtaining phosphorus and potassium fertilizers the exergy losses are by $32 \%$ lower than in the production of ammoniated superphosphate. The exergy performance efficiency of technological stage of drying when obtaining phosphorus and potassium fertilizers is $18 \%$ higher in comparison with the stage of granulation and drying in the production of ammoniated superphosphate [5] (85\% and $67 \%$, respectively).

Thus, the total exergy losses, and, accordingly, the energy costs on the course of obtaining phosphorus and potassium fertilizers are $30 \%$ lower than similar expenditures in the production of ammoniated superphosphate. Consequently, the indicators of energy efficiency of the production of phosphorus and potassium fertilizers will be larger and this technology saves more energy.

\section{Conclusions}

1. The main forms of the exergy losses are substantiated - due to the change in the magnitude of pressure of the medium at the input of the unit and at the output from it, through the walls of the unit to the environment and the heat exchange with finite differences in temperatures of technology flows at the input of the unit and at the output from it.

2. The presented method of determining the exergy expenditures is adapted to the developed technological process and allows, at each stage of the technology of phosphorus and potassium fertilizers, determining the articles of the exergy balance and the exergy losses. Its characteristic properties are identification of the sources of the heat losses from the irreversibility of processes in technological equipment and the ability to determine numerical values of the exergy losses of the considered technological process for making technical decisions with the purpose of decreasing the given losses.

3. The exergy balance of the technology of phosphorus and potassium fertilizers is calculated, which shows absence of the exergy flows and, accordingly, the exergy losses at the stages of mixing the raw material and granulation of the charge. At the stage of the drying of granules, up to $97 \%$ of exergy comes with the flue gases and up to $85 \%$ is consumed with the outgoing gases after a drum dryer, that is why the exergy losses are insignificant. At the stage of sieving the granules, up to $65 \%$ of exergy comes with the aspiration air for ventilation of the screen and only $16 \%$ is consumed with it at the output from the screen, that is why the exergy losses amount to $84 \%$ while the exergy performance efficiency is $16 \%$ only.

4. It is demonstrated that the drying of granules is the most energy-consuming stage in the technology of mineral phosphate fertilizers, for which the exergy losses in the absolute magnitude are the largest, but compose only $15 \%$ of the total input of thermal energy for drying, that is why the exergy performance efficiency reaches a rather high value of $85 \%$.

5 . By way of comparison the energy costs, we showed the decrease in the expenditures when obtaining phosphorus and potassium fertilizers by $30 \%$ in comparison to the widely used ammoniated superphosphate. 


\section{References}

1. Jarchow, M. E. Nitrogen fertilization increases diversity and productivity of prairie communities used for bioenergy [Text] / M. E. Jarchow, M. Liebman // GCB Bioenergy. - 2013. - Vol. 5, Issue 3. - P. 281-289. doi: 10.1111/j.1757-1707.2012.01186.x

2. Galichechi, S. Nitrogen fertilizer the effects on growing potato [Text] / S. Galichechi, M. Gashti azar // Journal of Biology and today's world. - 2013. - Vol. 2. - P. 335-338.

3. Johnston, A. E. A new approach to assessing phosphorus use efficiency in agriculture [Text] / A. E. Johnston, J. K. Syers // Better Crops. - 2009. - Vol. 93, Issue 3. -P. 14-16.

4. Masood, A. The effect of different levels of phosphorus from triple super phosphate chemical fertilizers and biological phosphate fertilizer (fertile 2) on physiological growth parameters of corn (sc 704) in Ahvaz weather conditions [Text] / A. Masood, M. Mani // International Journal of Plant, Animal and Environmental Sciences. - 2014. - Vol. 4, Issue 2. - P. 625-632.

5. Yukhimenko, N. P. Proizvodstvo ammonizirovannogo superfosfata. Ehksergeticheskie aspekty snizheniya ehnergozatrat [Text] / N. P. Yukhimenko, E. A. Karpovich, S. V. Vakal, R. N. Klimenko // Khimichna promyslovist Ukrayiny. - 2012. - Vol. 5. - P. 55-63.

6. Mukherjeea, S. Energy and exergy analysis of chemical looping combustion technology and comparison with pre-combustion and oxy-fuel combustion technologies for CO2 capture [Text] / S. Mukherjeea, P. Kumara, A. Yangb, P. Fennellc // Journal of Environmental Chemical Engineering. - 2015. - Vol. 3, Issue 3. - P. 2104-2114. doi: 10.1016/j.jece.2015.07.018

7. Laković, M. Exergy analyzing method in process integration of the nitric acid production plant [Text] / M. Laković, P. Živković, P. Rašković // Mechanical Engineering. - 2005. - Vol. 3, Issue 1. - P. 109-116.

8. Kol, S. Exergy analysis of Birla cement plant Satna: A case study [Text] / S. Kol, A.Chaube // International Journal of Scientific \& Engineering Research. - 2013. - Vol. 4, Issue 10. - P. 312-320.

9. Velasquez-Arredondo, H. Excergy efficiency analysis of chemical and biochemical stages involved in liquid biofuels productions processes [Text] / H. Velasquez-Arredondo, S. De Oliveira Junior, P. Benjumea // Energy. - 2012. - Vol. 41, Issue 1. - P. 138-145. doi: 10.1016/j.energy.2011.06.025

10. Kirova-Yordanova, Z. Application of the exergy method to environmental impact estimation: The ammonium nitrate production as a case study [Text] / Z. Kirova-Yordanova // Energy. - 2010. - Vol. 35, Issue 8. - P. 3221-3229. doi: 10.1016/j.energy.2010.03.063

11. Kliopova, I. Possibilities of increasing resource efficiency in nitrogen fertilizer production [Text] / I. Kliopova, I. BaranauskaitèFedorova, M. Malinauskiené, J. K. Staniškis // Clean Technologies and Environmental Policy. - 2016. - Vol. 18, Issue 3. - P. 901-914. doi: 10.1007/s10098-015-1068-9

12. Dincer, I. Energy, Entropy and Exergy Concepts and Their Roles in Thermal Engineering [Text] / I. Dincer, Y. A. Cengel // Entropy. - 2001. - Vol. 3, Issue 3. - P. 116-149. doi: 10.3390/e3030116

13. Bastianoni, S. Emergy as a function of exergy [Text] / S. Bastianoni, A. Facchini, L. Susani, E. Tiezzi // Energy. - 2007. - Vol. 32, Issue 7. - P. 1158-1162. doi: 10.1016/j.energy.2006.08.009

14. Lior, N. The exergy fields in transport processes: Their calculation and use [Text] / N. Lior, W. Sarmiento-Darkin, H. S. Al-Sharqawi // Energy. - 2006. - Vol. 31, Issue 5. - P. 553-578. doi: 10.1016/j.energy.2005.05.009

15. Luis, P. Exergy analysis of energy-intensive production processes: advancing towards a sustainable chemical industry [Text] / P. Luis, Bart Van der Bruggen // Journal of Chemical Technology and Biotechnology. - 2014. - Vol. 89, Issue 9. - P. $1288-1303$. doi: $10.1002 /$ jctb. 4422

16. Shargut, Y. Ehksergiya [Text] / Y. Shargut, R. Petela. - Moscow” Energiya, 1968. - 279 p.

17. Brodyanskij, V. M. Ehksergeticheskij metod i ego prilozheniya [Text] / V. M. Brodyanskij, V. Fratsher, K. Mihalek. - Moscow: Energoatomizdat, 1988. - 288 p.

18. Yukhimenko, N. P. Proizvodstvo sul'fata alyuminiya. Ehksergeticheskie aspekty snizheniya ehnergozatrat [Text] / N. P. Yukhimenko, S. V. Vakal // Khimichna promyslovist' Ukrayiny. - 2011. - Vol. 4. - P. 45-49. 